\title{
THE EFFECT OF THE STORE SERVICESCAPE ON THE CUSTOMERS REGARDING THE TELECOMMUNICATION SECTOR ${ }^{1}$
}

****

\section{TELEKOMÜNIIKASYON SEKTÖRÜNDE MAĞAZA HİZMET ORTAMININ MÜŞTERILER ÜZERINDEKİ ETKİSi}

\author{
Dr. Öğr. Üyesi Onur ÇELİK \\ Adana Alparslan Türkeş Bilim ve Teknoloji Üniversitesi \\ İşletme Fakültesi \\ Turizm İșletmeciliği Bölümü \\ ocelik@atu.edu.tr \\ ORCID: 0000-0002-8552-1133
}

\begin{abstract}
The competition among enterprises in the today's business world is acquiring more different dimensions day by day. The enterprises which maintain especially their technology-oriented activities are experiencing a period in which it is not possible for them to be one step ahead from their competitors through only improvements in their technological infrastructures. The competition wars in the telecommunication sector of which importance and potential is great as well are observed to be performed over physical evidence which constitutes one of the significant elements of the marketing mix (7P). Within this scope, the study was implemented to the telecommunication sector which shows an oligopoly market property in Turkey. The purpose of the study is to reveal the effects of the servicescape on the target audience in the telecommunication sector. The study was carried out in the Shopping Malls in the province of Adana by taking into consideration the brands of Turkcell, Vodafone and Turk Telekom which are carrying on their business in the telecommunication sector in Turkey. As a result of this study, reviewable 400 surveys were obtained and within this scope, descriptive statistics were used for the demographic information and simple linear regression analysis were implemented for total 4 scales which include 21 judgments. According to the data of hypothesis test, servicescape was observed to have positive effects on the perceived quality, brand image, brand loyalty.
\end{abstract}

Key Words: Servicescape, Perceived Quality, Brand Image, Brand Loyalty

Öz

Günümüz iş dünyasinda işletmeler arasindaki rekabet her geçen gün daha farkl boyutlar kazanmaktadır. Özellikle teknoloji odakl faaliyetlerini sürdüren işletmeler sadece teknolojik alt yapılarındaki iyileştirmeler ile rakiplerinden bir adım öne çıkabilmeleri mümkün olmayan bir dönemi yaşamaktadır. Önemi ve potansiyeli büyük olan telekomünikasyon sektöründe de rekabet savaşları hizmet pazarlaması karmasının (7P) önemli ayaklarından bir tanesi olan fiziksel unsurlar üzerinden de gerçekleştiği görülmektedir. Bu kapsamda çalışma Türkiye'de oligopol pazar özelliği gösteren telekomünikasyon sektöründe uygulanmıştır. Çalışmanın amacı telekomünikasyon sektöründe mağaza hizmet ortamının hedef kitle üzerindeki etkilerini ortaya koyabilmektir. Çallşma Türkiye'de telekomünikasyon sektöründe faaliyet gösteren Turkcell, Vodafone ve Turk Telekom markaları dikkat alınarak; Adana ilinde yer alan AVM'lerde gerçekleştirilmiştir. Araştırmanın sonucunda incelenebilir 400 ankete ulaşılmış, bu kapsamda demografik bilgiler için tanımlayıcı istatistikler kullanılırken, 21 yargıldan oluşan toplam 4 ölçek için ise basit lineer regresyon analizi uygulanmıştır. Hipotez test verilerine göre ise mağaza hizmet ortamının; algılanan kalite, marka imajı ve marka sadakati üzerinde pozitif yönde etkisinin olduğu görülmüştür.

Anahtar Kelime: Măgaza Hizmet Ortamı, Algılanan Kalite, Marka Imajı, Marka Sadakati

\footnotetext{
${ }^{1}$ This study was supported by Adana Alparslan Türkeş Science and Technology University under Scientific Research Projects (Project No: 17117003)
} 


\section{INTRODUCTION}

Remarkable and important figures are observed to be available when the telecommunication sector is reviewed across the world. As of January 2019, while about $67 \%$ of 7 billion 676 million people in the world has their own mobile telephone, internet utilization ratio is at the level of 57\% (KMPG, 2018). In 2018, while the world population showed an increase of $1,1 \%$, mobile telephone utilization ratio showed an increase of 2\% (KMPG, 2018). Concerning specific to Turkey, the growth data of the telecommunication sector shows an advance in parallel to the world. Although the telecommunication sector is an advanced and great sector in Turkey, seen that it is a sector which still has an important potential, shows a consistent growth and is expected to grow, when paying regard to the demographic structure of Turkey (KMPG, 2018).

The enterprises in the telecommunication sector are showing hard effort to improve their technological infrastructures from past to present in order to take place in the sector and obtain competitive advantage. However, only these efforts are not sufficient to thrust themselves to the forefront in terms of the competition nowadays. Because all enterprises in the sector are putting similar efforts into practice. For this reason, the competition in the sector has started to tend to be performed over other elements. Servicescape is probably the most outstanding element among others. Because in retail sector consumers evaluate their experience with servicescape (Kwon et. al. 2015). Physical evidence which is one of the elements of the marketing mix includes all physical factors which customers encounter from their entry to the stores to exit. Perception left by these all factors on the customers may have an overall effect from the general image of the enterprise to the purchase behaviors of the customers. Through increase of the importance attributed to the customer perception and experiences today, the servicescape is further overemphasized by both implementers and also researchers (Turley and Milliman 2000; Karakaşoğku and Arslan 2016).

Futher research are required due to inadequacy in the concept development in the store servicescape and the importance of the field (Spence et. al. 2014; Hoffman and Turley, 2002). Although studies are available in the international literature, studies evaluating the effect of the store environment on the consumer in Turkey are limited and these studies were carried out for retails which operate in different sectors. (Yalçın and Kocamaz, 2003; Akaydın, 2007; Dursun et al., 2013; Fettahlıoğlu, 2014; Karakaşoğlu and Aslan, 2016; Yüksekbilgili, 2016; İnan et al., 2016). Such studies have not been encountered as to specific to the telecommunication sector.

According to Harris and Ezeh (2008), international literature agrees with the opinion that the store servicescape has an effect on the behavior (Cronin, 2003; Foxall and Yani-de-Soriano, 2005), but the issue needs to be developed conceptually and more studies are required to be carried out (Bitner 1992; Tombs and McColl-Kennedy 2003, Foxall and Greenley 1999; Hoffman and Turley 2002). Also, few empirical studies regarding the effect of the store servicescape on the consumer behaviors and purchase decisions despite of the conceptual inadequacy are available (Bitner 1992; Cronin 2003). On the other hand, studies regarding the effect of the store servicescape on the purchase decisions in the international literature have emphasized the effect of a single element on the purchase decisions; for example, music, light, fragrance, colors etc. (Tantanatewin and Inkarojrit, 2016; Areni and Kim 1993; Sweeney and Wyber 2002; Biswas et. al. 2017; Areni and Kim 1994; Summers and Hebert 2001). Only a few studies (Morone et al. 2018; Wakefield and Blodgett 1996; Mattila and Wirtz 2001; Spangenverg et al. 2005) have analyzed the big picture. However, most studies carried out with regard to the store servicescape have addressed the social-interactive dimensions of the physical evidence (Tombs and McColl-Kennedy 2003). Through this table arising as a result of the literature research, the purpose and framework of the study was determined. The purpose of the study is to reveal the effect of the store servicescape in the telecommunication sector in Turkey on the perceived service quality, brand image and brand loyalty. Within the framework of this purpose, it is intended that this study will provide benefits to meet some deficits available in the literature and be a guide to the implementers as well.

\section{LITERATURE}

Servicescape is a kind of setting place where services are provided (Räisänen et. al. 2014). Store servicescape has several different definitions. Baker (1987) defined it as "physical environment', 
Kotler (1973) as 'atmospherics', Bitner (1992) as 'servicescape' and Turley and Milliman (2000) as 'marketing environment'. Even if definitions attributed to the store servicescape differ, generally accepted hypothesis on which studies performed with regard to the effect of the store servicescape on the customers are based as follows; customers perceive stimulus in their physical environment, solve its code and interpret, then make a decision at the end of this process (Engel et al. 1978). By this process consumers' perceptions of service functions and service quality are influenced by servicescape (Nilsson and Ballantyne, 2014).

Quality can be easily defined in manufacturing sectors but in service sector the phenomenon is getting more challenging to describe (Annamdevula and Bellamkonda, 2016). Perceived quality is an information package presented to the consumers for the question why they would like to purchase that brand instead of other brands (Yousaf, Zulfiqar et al. 2012, 328). According to Bitner (1992), physical evidence is required to position in the mind of the target audience as the services are abstract concepts and, in this sense, the store servicescape allows customers to generate the perceived quality in their mind. For example, physical evidence such as the store's design, color, fragrance, music etc. may provide to arise positive or negative perceptions about the quality in the mind of the customers.

An efficient connection is available on the quality perception which the store servicescape leaves on the customers (Hooper et.al. 2013; Kearney et al. 2012; Bitner, 1992; Brady and Cronin, 2001 and Spangenberg et al., 1996). Hence, it was asserted that physical evidence is the determinant of the perceived quality (Ward et al. 1992; Baker et al. 1994; Baker 1998; Aubert-Gamet and Cova 1999; Baker et al. 2002). The first hypothesis has been built within the framework of this literature;

H1: Store servicescape has an effect on the perceived quality.

Brand loyalty; According to Dick and Basu (1994), it is a behavioral action which is consistently sustained towards a brand by the decision maker among various alternatives. While making decisions, consumers demand to have good memories and experiences about brands (Shanti et. al. 2019). Servicescape is a way to serve brand experiences to consumers.

It is understood that the effect of the store servicescape on the brand loyalty is a comprehensive research subject when literature is examined (Shashikala et. al. 2013; Foxall and Greenley 1999; Cronin 2003; Foxall and Yani-de-Soriano 2005). It has been seen that store servicescape has an effect on the customers' emotions and on the tendency of the customers to continue or cease the purchase intention (Foxall and Greenley 1999; Lovelock 2001; Hoffman and Turley 2002; Tombs and McCollKennedy 2003). In this scope, the second hypothesis has been built as follows;

$\mathrm{H} 2$ : Store servicescape has an effect on the brand loyalty.

Brand image consists of perceptions reflected about the brand in related to some association of ideas generating in the customers' mind. Brand image is the big picture regarding the brand generating in the target audience's mind (Howard, 1989). On the other hand brand image can effect target audience's perception and feelings as well as their behaviors (Zhang, 2015).

Store servicescape shapes the brand image (Kisang et al. 2012). According to Booms and Bitner (1982), store servicescpae creates the brand image in the customers' mind. Also, according to Baker et al. (1994), improvements in the store servicescape conduces to the improvements in the brand image. The third hypothesis is as follows in the light of this information;

H3: Store servicescape has an effect on the brand image.

\section{METHODOLOGY}

The main audience of the study is the customers who have visited the stores of the brands operating in the telecommunication sector in Adana province physically at least once. Thus, more accurate evaluation of the store servicescape is aimed in the study to be carried out.

The main audience of the study is pretty large and to reach the full number is not possible due to both as material and also time limit. For this reason, sampling from the main audience was considered as appropriate. Based on the universe size, sampling figures are specified as 384 within the framework of 0,05 sampling error in cases where the main audience number exceeds 100.000 (Yazıcioğlu and 
Erdoğan, 2004). Also, according to Büyüköztürk et al. (2012), "In a multivariate study (including also multi regression analyses), sampling size must be 10 times or more of the variance number in the study preferably". By taking into consideration that 21 judgments are available in the survey of the study, a figure of about 210 and over may be sufficient.

Paying attention to this information in the study carried out, a high sampling number as possible as was tried to be obtained and 417 persons were reached. However, when surveys were reviewed, it has been determined that incomplete data is available in 17 surveys. For this reason, the study was carried out on the basis of 400 sampling number. As the sampling method, judgment sampling method was used. With this situation, it was aimed that the main audience representation value of the sampling would increase.

Surveys were performed face to face with the answerers in February, 2019. Survey includes 21 judgments as well as demographic questions. Judgments were structured through 5-point likert scale. The scales used in the study have been previously benefited in various studies and these scales' reliability has been proven. (Store Servicescape (7 items); Dabholkar et al., (1996); Demirci, (2000); Kurtuluş, (2001); Perceived Service Quality (9 items); Pappu et al. (2005, 2006), Brand Loyalty (3 items); Yoo et al., (2000), Brand Image (2 items); Lau and Lee (1999)).

Taking into consideration the study and the structure of Adana province, Shopping Malls were considered as the most correct places to reach the target audience. That the respective brands have a physical store in all shopping malls was efficient on this decision. In this study, "M1 Adana Shopping Mall" and "Optimum Adana Shopping Mall" which are two big shopping malls located in the province of Adana were determined as implementation place.

In the light of the information obtained as a result of the literature search, research model was formed. This model is as follows;

Figure 1: Research Model



Hypotheses were developed within the scope of the research model. Through the study conducted, the following hypotheses were tested.

H1: Store servicescape has an effect on the perceived quality.

H2: Store servicescape has an effect on the brand loyalty.

H3: Store servicescape has an effect on the brand image.

\section{ANALYSES}

Firstly, the demographic structured was addressed in the analysis of the data obtained in the study. Demographic data obtained by using the descriptive statistics are presented in Table 1. 
Table 1. Demographic Information

\begin{tabular}{|c|c|c|c|c|c|}
\hline \multicolumn{2}{|c|}{ Age } & \multicolumn{2}{|c|}{ Education } & \multicolumn{2}{|c|}{ Gender } \\
\hline Age Range & Percentage \% & Level & Percentage \% & F/M & Percentage \% \\
\hline $18-25$ & $16,0 \%$ & Primary education & $14,5 \%$ & Female & $39,7 \%$ \\
\hline $26-35$ & $22,8 \%$ & High School & $34,5 \%$ & Male & $60,3 \%$ \\
\hline $36-45$ & $27,3 \%$ & Associate degree & $10,3 \%$ & & \\
\hline $46-55$ & $20,8 \%$ & Bachelor's Degree & $30,3 \%$ & & \\
\hline $56-65$ & $11,0 \%$ & Master Degree & $9,8 \%$ & & \\
\hline Over 65 & $2,3 \%$ & Ph.D. & $0,8 \%$ & & \\
\hline
\end{tabular}

Based on the data, $60,3 \%$ of the participants is male and $39,7 \%$ is female. $86,7 \%$ of the participants is under the age of 55. When regarding as the education level, the highest participation with $34,5 \%$ is high school level and it is followed by bachelor's degree with a ratio of $30,3 \%$.

\subsection{Hypothesis Test Results}

Reliability analysis applied to the scale with 21 sub-statements (Table 2). According to Hair (2010) Cronbach Alpha value should be above 0,70 but also 0,60 is acceptable. Due to that the test results $(0,916)$ indicates the scale is reliable.

Table 2. Reliability Test Results

\begin{tabular}{|c|c|}
\hline Cronbach's Alpha & N of Items \\
\hline, 916 & 21 \\
\hline
\end{tabular}

Kaiser-Meyer-Olkin Test is used for adequacy of sampling to apply factor analysis. KMO value is acceptable between 0,5-1 but satisfactory value is above 0,70 (Malhotra, 1996). The test results show that KMO value is 0,915 , means sampling adequacy is highly acceptable. Also Bartlett Test is applied to understand; between variables whether relationships are significant and different from 0 (Hair, 1998). So Bartlett Test result is adequate.

Table 3. KMO and Bartlett's Test Results

\begin{tabular}{|l|l|c|}
\hline \multicolumn{2}{|l|}{ Kaiser-Meyer-Olkin Measure of Sampling Adequacy. } &, 915 \\
\hline \multirow{3}{*}{ Bartlett's Test of Sphericity } & Approx. Chi-Square & 3520,249 \\
\cline { 2 - 3 } & df & 136 \\
\cline { 2 - 3 } & Sig. &, 000 \\
\hline
\end{tabular}

In the light of the results factor analysis applied to the scale. According to Hair (2010) each variables in the factors should be above 0,30-,040, due to that 4 variables ( 3 from perceived quality, 1 from servicescape) excluded from the analysis. According to factor analysis 4 factors are revealed. They are; servicescape, perceived quality, brand loyalty and brand image. Total explained variance is 57,078 . 
Table 4. Pattern Matrix ${ }^{\mathrm{a}}$

\begin{tabular}{|c|c|c|c|c|c|c|}
\hline & \multicolumn{4}{|c|}{ Factor } & \multirow{2}{*}{\multicolumn{2}{|c|}{ Cronbach Alpha }} \\
\hline & 1 & 2 & 3 & 4 & & \\
\hline Perceived Quality3 &, 911 & & & & \multirow{6}{*}{0,899} & \multirow{17}{*}{0,913} \\
\hline Perceived Quality2 &, 871 & & & & & \\
\hline Perceived Quality4 &, 779 & & & & & \\
\hline Perceived Quality1 &, 676 & & & & & \\
\hline Perceived Quality6 &, 575 & & & & & \\
\hline Perceived Quality5 & ,473 & & & & & \\
\hline Image2 & &,- 808 & & & \multirow{2}{*}{0,838} & \\
\hline Image 1 & &,- 694 & & & & \\
\hline Servicescape 3 & & & ,811 & & \multirow{6}{*}{0,841} & \\
\hline Servicescape 2 & & &, 777 & & & \\
\hline Servicescape 4 & & &, 731 & & & \\
\hline Servicescape7 & & &, 539 & & & \\
\hline Servicescape 5 & & &, 508 & & & \\
\hline Servicescape6 & & &, 454 & & & \\
\hline Loyalty3 & & & &, 676 & \multirow{3}{*}{0,764} & \\
\hline Loyalty 2 & & & & ,645 & & \\
\hline Loyalty1 & & & &, 573 & & \\
\hline \multicolumn{7}{|c|}{ Extraction Method: Maximum Likelihood. } \\
\hline
\end{tabular}

On the purpose of carrying out hypothesis tests, the average of the answers given by each participant to the sub-groups was taken and hypotheses specified were tested through Regression analysis. All analyses were carried out through simple linear regression and regression coefficients occurred at an important level of 5\% through unpaired $\mathrm{T}$ test. The direction of the relationship among variables was occurred at an important level of 5\% through Pearson correlation analysis.

Table 5. ANOVA ${ }^{\mathrm{a}}$

\begin{tabular}{|c|c|c|c|c|c|c|}
\hline \multicolumn{2}{|c|}{ Model } & Sum of Squares & df & Mean Square & $\mathrm{F}$ & Sig. \\
\hline \multirow[t]{3}{*}{1} & Regression & 118,147 & 1 & 118,147 & 236,946 &, $000^{\mathrm{b}}$ \\
\hline & Residual & 198,452 & 398 & ,499 & & \\
\hline & Total & 316,599 & 399 & & & \\
\hline
\end{tabular}

As a result of the simple linear regression analysis conducted, it has been seen that store servicescape has positive effect on the perceived quality and this effect is significant. (Table 5). Within this framework, H1 hypothesis is supported. 
Table 6. Model Summary

\begin{tabular}{|c|c|c|c|c|}
\hline Model & $\mathrm{R}$ & R Square & $\begin{array}{c}\text { Adjusted R } \\
\text { Square } \\
\end{array}$ & $\begin{array}{l}\text { Std. Error of the } \\
\text { Estimate }\end{array}$ \\
\hline 1 &, $611^{\mathrm{a}}$ & ,373 & 372 & ,70613 \\
\hline
\end{tabular}

$\mathrm{R}^{2}$ value is obtained as 0,373 . This value is an indicator that $37 \%$ of the quality occurred as a result of impression obtained from the store servicescape. When regarding the multiplicity of the variables to affect the quality perception of a brand, it is remarkable that weight of variable is at level of $37 \%$ (Table 6 ).

Table 7. Coefficients ${ }^{\mathrm{a}}$

\begin{tabular}{|c|c|c|c|c|c|c|}
\hline & & \multicolumn{2}{|c|}{ Unstandardized Coefficients } & \multirow{2}{*}{$\begin{array}{c}\text { Standardized } \\
\text { Coefficients }\end{array}$} & \multirow[b]{2}{*}{$\mathrm{t}$} & \multirow[b]{2}{*}{ Sig. } \\
\hline \multicolumn{2}{|c|}{ Model } & B & Std. Error & & & \\
\hline \multirow[t]{2}{*}{1} & (Constant) & 602 & 195 & & 3,090 & 002 \\
\hline & servicescape &, 748 & 049 & ,611 & 15,393 & ,000 \\
\hline
\end{tabular}

Table 7 shows that the beta coefficient of the variable is 0.748 . The positive coefficient indicates that the relationship between the independent variable (servicescape) and the dependent variable (perceived quality) is positive. Also significance value $(\mathrm{p}=0,000 ; \mathrm{t}=15,393)$ proves that the model is statistically significant.

Table 8. ANOVA ${ }^{\mathrm{a}}$

\begin{tabular}{|l|l|l|l|l|l|l|}
\hline \multicolumn{2}{|l|}{ Model } & Sum of Squares & df & Mean Square & F & Sig. \\
\hline \multirow{3}{*}{1} & Regression & 60,603 & 1 & 60,603 & 76,105 &, $000 \mathrm{~b}$ \\
\cline { 2 - 7 } & Residual & 316,928 & 398 &, 796 & & \\
\cline { 2 - 7 } & Total & 377,531 & 399 & & & \\
\hline
\end{tabular}

Based on the analysis, $\mathrm{H} 2$ hypothesis is supported. The result stating that store servicescape has effect on the brand loyalty (Tablo 8 ).

Table 9. Model Summary

\begin{tabular}{|l|r|r|r|r|}
\hline Model & $\mathrm{R}$ & R Square & $\begin{array}{l}\text { Adjusted R } \\
\text { Square }\end{array}$ & $\begin{array}{l}\text { Std. Error of the } \\
\text { Estimate }\end{array}$ \\
\hline 1 &, $401^{\mathrm{a}}$ &, 161 &, 158 &, 89236 \\
\hline
\end{tabular}

It is seen that positive changes and developments to be performed in the store servicescape will have a positive effect on the loyalty of the target audience to the respective brand. $\mathrm{R}^{2}$ value as a result of the regression analysis is 0,161 . This result states that the store servicescape renders a part of $16 \%$ of loyalty levels of the customers (Table 9). 
Table 10. Coefficients ${ }^{\mathrm{a}}$

\begin{tabular}{|c|c|c|c|c|c|c|}
\hline & & \multicolumn{2}{|c|}{ Unstandardized Coefficients } & \multirow{2}{*}{$\begin{array}{c}\text { Standardized } \\
\text { Coefficients }\end{array}$} & \multirow[b]{2}{*}{$\mathrm{t}$} & \multirow[b]{2}{*}{ Sig. } \\
\hline \multicolumn{2}{|c|}{ Model } & B & Std. Error & & & \\
\hline \multirow[t]{2}{*}{1} & (Constant) & 1,623 &, 246 & & 6,593 &, 000 \\
\hline & servicescape &, 536 & 061 &, 401 & 8,724 & 000 \\
\hline
\end{tabular}

The beta coefficient of the variable is 0.536 . Significance value $(p=0,000 ; t=8,724)$ shows that the model is statistically significant.

Table 11. ANOVA ${ }^{\mathrm{a}}$

\begin{tabular}{|c|c|c|c|c|c|c|}
\hline \multicolumn{2}{|c|}{ Model } & Sum of Squares & $\mathrm{df}$ & Mean Square & $\mathrm{F}$ & Sig. \\
\hline \multirow[t]{3}{*}{1} & Regression & 76,451 & 1 & 76,451 & 63,253 &, $000^{\mathrm{b}}$ \\
\hline & Residual & 481,046 & 398 & 1,209 & & \\
\hline & Total & 557,497 & 399 & & & \\
\hline
\end{tabular}

H3 hypothesis is supported. It has been found that the store servicescape has positive effect on the brand image (Table 11).

Table 12. Model Summary

\begin{tabular}{|l|r|r|r|c|}
\hline Model & \multicolumn{1}{|c|}{$\mathrm{R}$} & R Square & \multicolumn{1}{|c|}{$\begin{array}{c}\text { Adjusted R } \\
\text { Square }\end{array}$} & $\begin{array}{c}\text { Std. Error of the } \\
\text { Estimate }\end{array}$ \\
\hline 1 &, $370^{\mathrm{a}}$ &, 137 &, 135 & 1,09939 \\
\hline
\end{tabular}

$\mathrm{R}^{2}$ value is obtained as 0,137 in this hypothesis test. It is an indicator that $13 \%$ of the brand image occurred as a result of impression obtained from the store servicescape (Table 12).

Table 13. Coefficients ${ }^{\mathrm{a}}$

\begin{tabular}{|c|c|c|c|c|c|c|}
\hline \multicolumn{2}{|c|}{ Model } & \multicolumn{2}{|c|}{ Unstandardized Coefficients } & \multirow{3}{*}{$\begin{array}{c}\text { Standardized } \\
\text { Coefficients }\end{array}$} & \multirow[b]{3}{*}{2900} & \multirow[t]{3}{*}{ Sig. } \\
\hline & & $\mathrm{B}$ & Std. Error & & & \\
\hline \multirow[t]{2}{*}{1} & (Constant) &, 880 &, 303 & & & \\
\hline & servicescape & ,602 &, 076 &, 370 & 7,953 &, 000 \\
\hline
\end{tabular}

The constant value is significant at 0,004. The beta coefficient of the variable is ,602. According to significance value $(\mathrm{p}=, 000 \mathrm{t}=7953)$ the model is statistically significant.

\section{RESULTS}

This study was designed in order to reveal the effect of the store servicescape on the perceived service quality, brand image and brand loyalty. It is aimed to meet the deficit recognized in the literature and also to be a guide for the implementers.

The study was carried out with 417 participants, but 400 data was obtained as usable. Descriptive statistics, factor analysis and simple linear regression analysis applied to data. Based on the results obtained, four hypotheses were supported. Through H1 hypothesis, it has been found that 
the store servicescape has positive effect on the perceived quality. The result obtained shows parallelism with the literature (Massicotte et. al. 2011; Ward et al., 1992; Baker et al., 1994; Baker, 1998; Aubert-Gamet and Cova, 1999; Baker et al., 2002; Bitner, 1992; Rust and Oliver 1994; Rys et al. 1987; Zeithaml et al., 1990). While describing the store servicescape, Kotler (1973) also states it as the factors affecting the customers' perceptions. In the study carried out regarding the telecommunication sector in South Africa, it has been emphasized that the perceived quality should show a significant difference in terms of the competition for the enterprises and so, the enterprises in the telecommunication sector need to pay attention to the store servicescape so as to increase the behavioral intentions of their customers (Ngwenya, M. 2017).

Based on the $\mathrm{H} 2$ hypothesis is supported, the store servicescape has effect on the brand loyalty. Foxall and Greenley (1999), Cronin (2003), Foxall and Yani-de-Soriano (2005) also emphasized in their studies that the store servicescape has positive effect on the brand loyalty and this effect is so significant. Moreover, the findings stating that fragrance (Hallett and Silver, 2004, Takagi, 1989, Hirsch, 1991, Hunter, 1995), music (Yalch and Spangenberg, 1990; Chebat et al., 1993; Dube' et al., 1995, Areni and Kim, 1993, North and Hargreaves, 1996, Milliman, 1986), esthetic (Nguyen and Leblanc, 2002, Bitner, 1992), which are the variables of the store servicescape, have effect on the brand loyalty, purchase intentions, the store's sales, duration spent in the store, moods of the customers are rather prevalent.

After obtaining that the store servicescape has effect on the brand image, $\mathrm{H} 3$ hypothesis is also supported. According to Belizzi and Hite (1992), the store servicescape has positive effect on the brand image. On the other hand, Joanna et al. (2011) referred to the importance of the role of the store serviceascape and employees in order to deliver and strengthen the brand image which the enterprises desire to their shareholders in their studies. Jang et al. (2015) emphasized in a study conducted regarding restaurant enterprises that the store servicescape has effect on the restaurant brand image. A similar result was also obtained in the study which was carried out by Durna et al. (2015). Durna emphasized that the store servicescape has positive effect on the brand image and the image has a mediation influence between the store servicescape and behavioral intention as well.

Based on the results, it has been seen that the brands will obtain an increase in their perceived service quality, brand image and brand loyalty through the returns of the improvements to be made in the physical elements of the stores. Consequently, the recommendation to be given to the implementers is as follows; if they allocate resources to their store servicescape and design their physical elements as appropriate to their target audience by the experts, this will provide a considerable benefit to the enterprises in the telecommunication sector.

The study conducted was carried out within a certain framework due to material reasons and time limit. For example, the province of Adana was selected as the baseline as the target audience. In the future studies, implementing on the people in different regions, different cultures and with different socio-economic level will be beneficial. On the other hand, other sectors may be analyzed apart from the telecommunication sector. Also investigation on consumer satisfaction and pleasure can attribute to literature because according to Chang (2016) store servicescape has effect on the different feels of the customers such as satisfaction pleasure and emotion.

\section{REFERENCES}

AKAYDIN, H. (2007), Perakende Mağaza Atmosferinin Müşterilerin Satın Alma Kararı Üzerindeki Rolü: Eskişehir İlindeki Alışveriş Merkezi Müşterileri İle Bir Araştırma, Yüksek Lisans Tezi, Eskişehir Anadolu Üniversitesi Sosyal Bilimler Enstitüsü, Eskişehir.

ALAN D. and KUNAL B., (1994), "Customer Loyalty: Toward an Integrated Conceptual Framework" Journal of the Academy of Marketing Science, 22, 2, 99-113,

ANNAMDEVUlA, S., and BELlAMKONDA, R. S., (2016), Effect Of Student Perceived Service Quality On Student Satisfaction, Loyalty And Motivation In Indian Universities: Development Of Hieduqual. Journal of Modelling in Management, 11(2), 488-517. 
ARENI, CHARLES and KIM, DAVID (1994), "The Influence Of In-Store Lighting On Consumers' Examination Of Merchandise In A Wine Store", International Journal of Research in Marketing, Vol. 11, pp. 117-25.

ARENI, CHARLES and KIM, DAVID. (1993), "The Influence Of Background Music On Shopping Behaviour: Classical Versus Top-40 Music In A Wine Store, in McAlister, L. and Rothschild, M.L. (Eds)", Advances in Consumer Research, Association for Consumer Research, Provo, UT,pp. 336-40.

AUBERT-GAMET V. and COVA, B., (1999), "Servicescapes: From Modern Non-Places To Postmodern Common Places" Journal of Business Research, Vol. 44, pp. 37-45.

BAKER J. (1987), "The Role Of The Environment In Marketing Services: The Consumer Perspective In Czepiel," J., Congram, C.A. and Shanahan, J. (Eds), The Services Challenge: Integrating for Competitive Advantage, American Marketing Association, Chicago, IL, pp. 79-84.

BAKER, J., LEVY M. and GREWAL, D. (1992). "An Experimental Approach To Making Retail Store Environmental Decisions",Journal of Retailing, Vol.68, No.4, s.445-460

BAKER, J., GREWAL, D. and PARASURAMAN, (1994), “The Influence Of Store Environment On Quality Inferences And Store Image", Journal of the Academy of Marketing Science, Vol. 22 No. 4, pp. 328-39.

BAKER, J., PARASURAMA,, GREWAL, D. and VOSS G. (2002), "The Influence Of Multiple Store Environment Cues On Perceived Merchandise Value And Patronage Intentions," Journal of Marketing, Vol. 66, April, pp. 120-41.

BELLIZZI, J. A., and HITE, R. E. (1992). Environmental Color, Consumer Feelings, And Purchase Likelihood. Psychology \& Marketing, 9(5), 347-363.

BISWAS, D., SZOCS, C., CHACKO, R., WANSINK, B., (2017), Shining Light On Atmospherics: How Ambient Light Influences Food Choices. J. Mark. Res. 54 (1), 111-123.

BITNER M. J. (1992) "Servicescape: The Impact of Physical Surroundings on Customers and Employees," Journal of Marketing, 56(2), pp. 57-71.

BOOMS, B. and BITNER M. J. (1982), Marketing Services By Managing The Environment, "Cornell Hospitality Quarterly", Vol. 23 No. 1, pp. 35-40.

BRADY M., and CRONIN, J. (2001), "Some New Thoughts On Conceptualizing Perceived Servicequality: A Hierarchical Approach,” Journal of Marketing, Vol. 65, July, pp. 34-49

BÜYÜKÖZTÜRK, Ş., KILIÇ Ç., E., AKGÜN, Ö. E., KARADENIZ, Ş., DEMIREL, F. (2012). Örnekleme Yöntemleri. http://w3.balikesir.edu.tr/ msackes/wp/wpcontent/uploads/2012/03/BAY-Final-Konulari.pdf 03.07.2019

CHEBAT, J.C., GELINAS-CHEBAT, C. and FILIATRAULT, P. (1993), "Interactive Effects Of Music And Visual Cues On Time Perception: An Application To Waiting Lines In Banks", Perceptual and Motor Skills, Vol. 77, pp. 995-1020.

CHANG, K.C., (2016), Effect Of Servicescape On Customer Behavioral Intentions:Moderating Roles Of Service Climate And Employee Engagement. Int. J. Hospital.Manage. 53 (1), 116-128.

CRONIN, J. Jr (2003), "Looking Back To See Forward In Services Marketing: Some Ideas To Consider, Managing Service Quality, Vol. 13 No. 5, pp. 332-7.

DEMİRCI, F., (2000), "Yerleşim Yerlerine Yakınlığın Alışveriş Müşterisi Olma Üzerindeki Etkileri”, 5. Ulusal Pazarlama Kongresi, Akdeniz Üniversitesi, 16-18 Kasım, 301-312.

DUBE', L., CHEBAT, J. and MORIN, S. (1995), "The Effects Of Background Music On Consumers' Desire To Affiliate In Buyer-Seller Interactions", Psychology and Marketing, Vol. 12 No. 4, pp. 305-19. 
DURNA, U., DEDEOGLU, B. B., and BALİKÇİGLU, S. (2015). The Role Of Servicescape And Image Perceptions Of Customers On Behavioral Intentions In The Hotel Industry. International Journal of Contemporary Hospitality Management, 27(7), 1728-1748.

DURSUN T.,, OSKAYBAŞ, K., ve GÖKMEN C., (2013), "Mağaza Atmosferinin İçgüdüsel Satın Almaya Etkisi Ve Hazır Giyim Sektöründe Bir Araştırma" Marmara Üniversitesi İ.İ.B. Dergisi Cilt XXXV, Sayı II, S. 233-260

ENGEL J. K.,, and DAVID B, R., 1978. Consumer Behavior. Dryden Press, New York.

FETTAHLIOĞLU S., (2014), Tüketicilerin Mağaza Atmosferinden Etkilenme Düzeylerinin Demografik Faktörler Açısından İncelenmesi, Akademik Araştırmalar ve Çalışmalar Dergisi Yı1 6 - Sayı 11 ss. $27-40$

JANG, Y., RO, H., KIM, T., (2015), Social Servicescape: The Impact Of Social Factors On Restaurant Image And Behavioral Intentions. Int. J. Hosp. Tour. Adm. 16 (3), 290-309.

JOANNA M., JODY E., KERRIE B., and FELIX M., (2011) "Corporate Image In The Leisure Services Sector", Journal of Services Marketing, Vol. 25 No. 3, pp. 190-201

FOXALL G., and GREENLEY G., (1999), “Consumers' Emotional Responses To Service Environments, Journal of Business Research, Vol. 46, pp. 149-58.

FOXALL, G., and YANI-De-SORIANO (2005), "Situational Influence On Consumers' Attitude And Behaviour", Journal of Business Research, Vol. 58, pp. 518-25.

GEOK T., L., and SOOK H., L., (1999), "Consumer Trust in a Brand and The Link to Brand Loyalty", Journal of Market Focused Management, Vol.4.

GREWAL D.,, KRISHNAN, B., JULIE, B., N., (1998), "The Effect Of Store Name, Brand Name And Price Discounts On Consumers' Evaluations And Purchase Intentions" Journal of Retailing 74 (3), 331-352.

HAIR, JOSEPH F., ROLPH E. ANDERSON, RONALD L. TATHAM VE WILLIAM C. BLACK (1992), Multivariate Data Analysis with Readings, Third Edition, Macmillan Publishing Company, New York.

HAIR, J. F., BLACK W. C., BABIN B. J. VE ANDERSON R. E. (2010). Multivariate Data Analysis, A Global Perspective (7. Issue), NJ: Pearson.

HALLETT, V. and SILVER, M. (2004), "Scents and Sensibility", US News \& World Report, Vol. 137 No. 18, pp. D2-D3.

HARRIS, L. C., and EZEH, C. (2008). Servicescape And Loyalty Intentions: An Empirical Investigation. European Journal of Marketing, 42(3/4), 390-422.

HIRSCH, A.R. and GAY, S.E. (1991), "The Effect Of Ambient Olfactory Stimuli On The Evaluation Of a Common Consumer Product", Paper Presented At The 13th Annual Meeting of the Association for Chemoreception Science, Sarasota, FL

HOFFMAN D.. and TURLEY (2002) "Atmospherics, Service Encounters and Consumer Decision Making: An Integrative Perspective", Journal of Marketing Theory and Practice, 10, pp. 33-47.

HOOPER, D., COUGHLAN, J., \& R. MULLEN, M. (2013). The Servicescape As An Antecedent To Service Quality And Behavioral Intentions. Journal Of Services Marketing, 27(4), 271-280.

HOWARD, J., (1989), Consumer Behavior In Marketing Strategy, Prentice-Hall,Inc.

HUNTER, B.T. (1995), "The Sales Appeals Of Scents (Using Synthetic Food Scents To Increase Sales)", Consumer Research Magazine, Vol. 18 No. 10, pp. 8-10.

İNAN H., ZEREN D., DOĞAN S., H.,, (2016), "Hizmet Sektöründe Tekrar Satın Alma Niyeti Üzerine Bir Araştırma" Çukurova Üniversitesi İİBF Dergisi Cilt 20 Say 2 Ss.41-52 
KARAKAŞOĞLU M., ve ARSLAN M.,, (2016), "Mağaza Hizmet Ortamının Marka İmajına Ve Satın Alma Niyetine Etkisi: P\&B VE H\&M Örneği" Marmara Üniversitesi Öneri Dergisi, Cilt 12, Say1 46 ss. 223-243

KAUPPINEN-RÄISÄNEN， H., RINDELL， A., and ÅBERG， C. (2014), Conveying Conscientiousness: Exploring Environmental Images Across Servicescapes, Journal of Retailing and Consumer Services, 21(4), 520-528.

KELLER K., L., (1993), “Conceptualizing, Measuring, And Managing Customer-Based Brand Equity, Journal of Marketing, Volume: 57 No:1.

KELLER K., L.,, (2003), "Strategic Brand Management, Building, Measuring and Managing Brand Equity”, New Jersey: Prentice Hall,

KIM, W.G., MOON, J.M., (2009), Customers' Cognitive, Emotional, And Actionableresponse To The Servicescape: A Test Of The Moderating Effect Of The Restauranttype. Int. J. Hospital. Manage. 28 (1), 144-156.

KISANG R.,, HYE-RIN L.,, WOO G., K., (2012) “The Influence Of The Quality Of The Physical Environment, Food, And Service On Restaurant Image, Customer Perceived Value, Customer Satisfaction, And Behavioral Intention" International Journal of Contemporary Hospitality Management, Vol. 24 Issue: 2, pp.200

KPMG (2018), "Telekomünikasyon Sektörüne Bakış" https://assets.kpmg/content/dam/kpmg/tr/pdf/2018/01/sektorel-bakis-2018-telekom.pdf 08.07.19

KOTLER, P., (1973). “Atmospherics As A Marketing Tool”, Journal of Retailing, Vol.49,-No.4, s.50

KURTULUŞ, S., (2001), "Perakendeci Markası ve Üretici Markası Satın Alanların Tutumları Arasında Farklılık Var mı?”,Pazarlama Dünyası Dergisi, Yı1: 5: 9-14.

KWON, R. H., KIM, K. J., KIM, K. H., HONG, Y. S., \& KIM, B. (2015). Evaluating Servicescape Designs Using A Vr-Based Laboratory Experiment: A Case Of A Duty-Free Shop. Journal of Retailing and Consumer Services, 26, 32-40.

MALHOTRA, N. K. (1996). Marketing Research: An Applied Orientation, Second Edition, Printice Hall International

MASSICOTTE,M.C.,MICHON,R.,CHEBAT,J.C.,JOSEPHSIRGY,M.,BORGES,A., (2011) Effects of Mall Atmosphere On Mall Evaluation: Teenage Versus Adult Shoppers. J.Retail. Consum. Serv.18(1),74-80.

MILLIMAN, R. (1986), “The Influence Of Background Music On The Behaviour Of Restaurant Patrons", Journal of Consumer Research, Vol. 13 No. 2, pp. 286-289

MORONE, A., NEMORE, F., \& SCHIRONE, D. A. (2018). Sales Impact Of Servicescape's Rational Stimuli: A Natural Experiment. Journal of Retailing and Consumer Services, 45, 256-262.

NILSSON, E., and BALLANTYNE, D. (2014), Reexamining The Place Of Servicescape In Marketing: A Service-Dominant Logic Perspective, Journal of Services Marketing, 28(5), 374379.

NORTH, A.C. and HARGREAVES, D.J. (1996), “The Effects Of Music On Responses To A Dining Area", Journal of Environmental Psychology, Vol. 16, pp. 55-64.

LLOYD, H.,, CHRIS E., (2008) "Servicescape and Loyalty Intentions: An Empirical Investigation," European Journal of Marketing, Vol. 42 Issue: 3/4, pp.390-422,

LOVELOCK, C.,r (2001), “Services Marketing: People, Technology, Strategy, 4th ed., Prentice-Hall, Englewood Cliffs, NJ.

MATTILA, A., and WIRTZ J., (2001), "Congruency Of Scent And Music As A Driver Of In-Store Evaluations And Behaviour", Journal of Retailing, Vol. 77 No. 2, pp. 273-89. 
NGUYEN, N. and LEBLANC, G. (2002), "Contact Personnel, Physical Environment And The Perceived Corporate Image Of Intangible Services By New Clients", International Journal of Service Industry Management, Vol. 13 Nos 3/4, pp. 242-62.

NGWENYA, M. (2017), “Analysing Service Quality Using Customer Expectations And Perceptions In The South African Telecommunication Industry" IEEE International Conference on Industrial Engineering and Engineering Management (IEEM) (pp. 1094-1097). IEEE.

PAPPU R.,, QUESTER P., and COOKSEY R.,, (2005), "Consumer-Based Brand Equity: İmproving The Measurement, Empirical Evidence", The Journal of Product and Brand Management, 14(3):143-54.-223,

PAPPU R.,, QUESTER P., and COOKSEY R.,,, (2006), "Consumer-Based Brand Equity And Country-Of-Origin Relationships, European Journal of Marketing, 40(5/6):696-717.

PRATIBHA D., DAYLE. T., and JOSEPH R., (1996), "A Measurement Of Service Quality For Retail Stores: Scale Development And Validation", Journal of the Academy of Marketing Science, Vol. 24 No. 1, pp. 3-16.

ROMANIUK, J.,, SHARP, B., (2003). "Measuring Brand Perception: Testing Quantity And Quality”. Journal of Targeting Measurement and Analysis for Marketing 11 (3), 218-229.

RUST, R., OLIVER, R.,, (1994) "Service Quality: Insights and Managerial Implications from the Frontier in Service Quality: New Directions in Theory and Practice". Sage, Thousand Oaks, CA, pp. 1-20.

RYS, F., and LUERY, (1987) "Value = Quality? Are Service Value And Service Quality Synonymous: A Decompositional Approach. In: Surprenant, C. (Ed.)", Add Value to Your Service. AMA, Chicago, IL, pp. 25-28.

SHANTI, M., SUNARYO, S., and ROFIQ, A. (2019). "Cognitive-Affective Aspects Of Forming Brand Loyalty" Jurnal Aplikasi Manajemen, 17(2), 275-284.

SHASHIKALA, R., \& SURESH, A. M. (2013). Building Consumer Loyalty Through Servicescape In Shopping Malls. IOSR Journal of Business and Management, 10(6), 11-17.

SPANGENBERG, E., CROWLEY, A., and HENDERSON, P., (1996), "Improving The Store Environment: Dool Factory Cues Affect Evaluations And Behaviors"?, Journal of Marketing, Vol. 60, April, pp. 67-80.

SPANGENBERG E., GROHMANN, B., and SPROTT, D., (2005), "It's Beginning To Smell (And Sound) A Lot Like Christmas: The Interactive Effects Of Ambient Scent And Music In A Retail Setting", Journal of Business Research, Vol. 58, pp. 1583-9.

SPENCE, C., PUCCINElli, N. M., GREWAL, D., \& ROGGEVEEN, A. L. (2014). Store Atmospherics: A Multisensory Perspective. Psychology \& Marketing, 31(7), 472-488.

SUMMERS, T, and HEBERT P., (2001), "Shedding Some Light On Store Atmospherics: Influence Of Illumination On Consumer Behaviour", Journal of Business Research, Vol. 54 No. 2, pp. 14550 .

SWEENEY, J., and WYBER, F., (2002), "The Role Of Cognitions And Emotions In The MusicApproach-Avoidance Behaviour Relationship”, Journal of Services Marketing, Vol. 16 No. 1, pp. 51-69.

TAKAGI, S.F. (1989), Human Olfaction, University of Tokyo Press, Tokyo.

TANTANATEWIN, W., INKAROJRIT, V., (2016). Effects of Color And Lighting On Retail Impression And Identity. J. Environ. Psychol. 46, 197-205.

TOMBS, A., and MCCOLL-KENNEDY J., (2003), "Social-Servicescape Conceptual Model", Marketing Theory, Vol. 3 No. 4, pp. 447-75.

TURLEY and MILLIMAN, R., (2000). "Atmospheric Effects On Shopping Behavior: A Review Of The Experimental Evidence". Journal of Business Research 49 (2), 193-211. 
TREASA K., JOSEPH C., And AILEEN K., (2012), "An Exploration of the Effects of the Servicescape on Customer and Employee Responses in a Grocery Retail Context", Irısh Journal Of Management ss. 71-91

USMAN Y., RIDA Z., MADIHA A., and MOHSIN A., (2012), "Studying Brand Loyalty In The Cosmetics Industry", Scientific Journal of Logistics, 8 (4), 327-337

WAKEFIELD, K., and BLODGETT, J., (1994), “The Importance Of Servicescapes In Leisure Service Settings", Journal of Services Marketing, Vol. 8 No. 3, pp. 66-76.

WARD J., BITNER M., J., and BARNES J., (1992), "Measuring The Prototypicality And Meaning Of Retail Environments", Journal of Retailing, Vol. 68 No. 2, pp. 194-220.

WOO G. K., YUN J., M., (2009), “Customers' Cognitive, Emotional, And Actionable Response To The Servicescape: A Test Of The Moderating Effect Of The Restaurant Type" International Journal of Hospitality Management144-156

WU (2007). "The Study Of The Brand Image, Perceived Quality, Brand Loyalty And Repurchase Intention: Chinese Meat Process Industry As An Examples" Unpublished master thesis, Kun Shan University of Technology", Taiwan.

YALCH, R.F. and SPANGENBERG, E.R. (1990), "Effects Of Store Music On Shopping Behaviour", Journal of Consumer Marketing, Vol. 7 No. 2, pp. 55-63.

YALÇIN M., ve KOCAMAZ T., (2003), "The Effectts Of Store Atmosphere Attributes An Store Loyalty Intentions Of Hypermarket/Süpermarket Customers", Marmara Üniversitesi İ.İ.B.F Dergisi Cilt: 18

YAZICIOĞLU Y., ve ERDOĞAN S., (2004) SPSS Uygulamalı Bilimsel Araştırma Yöntemleri, Detay Yayıncılık, Ankara

YOO B., DONTHU N., and LEE S., (2000), “An Examination Of Selected Marketing Mix Elements And Brand Equity" Journal of the Academy of Marketing Science, 28(2):195-211

YÜKSEKBİLGíli̇ Z., (2016), Hızlı Moda Tüketicilerinin Mağaza Atmosferine Verdikleri Önemin Ölçülmesi İçin Bir Ölçek Geliştirme Çalışması: Avrasya Mağaza Atmosfer Ölçeği, Akademik Sosyal Araştırmalar Dergisi, Y11: 4, Sayı: 30 444-473

ZHANG, Y. (2015). The Impact of Brand Image On Consumer Behavior: A Literature Review. Open Journal Of Business and Management, 3(1). 